\title{
THE PRISONER OF GENDER: PANOPTICON, PERSUASION, AND SURVEILLANCE OF WOMEN IN KAVITA KANÉ'S MENAKA'S CHOICE
}

\begin{abstract}
In the mythology-inspired novel Menaka's Choice (2016), Kavita Kané discovers that the female body is continuously perceived both as an object of sexual desire and as an individual being by disrupting the conventional understanding of Apsara Menaka. Using Foucault's concept of docile bodies and organic individuality the paper studies how power, in the form of 'system', imposes docility on women's bodies. The paper weaves the potential for feminist thought as the novel rediscovers the recondite experiences that have been shrouded for centuries by giving central position to silent agents of Hindu mythology. Eventually, it attempts to analyse the act of seduction from the context of gender and how the individual tries to resist that disciplinary system.
\end{abstract}

Keywords: docile bodies; individuality; apsaras; Hindu mythology; panopticon.

Hindu mythology has remained a favoured ground for the Indian popular culture. Hindu mythology inspired novels that have become popular with readers over the past few years, as they reflect alternate ideological and religious perspectives. These retellings of the traditional mythical stories challenge the established grand narratives of the Hindu epics. According to the renowned Hindu philosopher and saint, Shri Aurobindo, "The Hindu mind, in one sense, is the most concrete in the world. It seeks after abstraction yet is it never satisfied so long as it remains abstraction" (Aurobindo 20). His observation holds true as many contemporary Indian writers are approaching mythology and rewriting mythical stories from various points of view. Taking into account the literary representations, many women writers have attempted to rewrite the hypermasculine Hindu epics like the Ramayana and the Mahabharata, passionately, from a women's point of view. One can find the revisioning of these epics in The Palace of Illusions (2008) by Chitra Banerjee Divakurni, Jaya: An Illustrated Retelling of the Mahabharata (2010), Shikhandi: And Other Tales They Don't Tell You (2014), and The

\footnotetext{
* Department of Humanities and Social Sciences, Roorkee; India.
} 
Book of Ram (2012) by Devdutt Pattnaik, Yajanaseni: The Story of Draupadi (1984) by Pratibha Ray, just to mention few of them.

Kavita Kané (b 1966) is equally farsighted in underlining the need for women's voice in her narratives and goes on to generate gender sensitivity by focusing on the most overlooked mythological women characters. Her novels could be regarded as 'feminist manifesto' as she has deconstructed the Hindu mythology from a feminist point of view, thereby defining the malleability of mythology. In this way, Kané reconfigures the patriarchal power system. The novel Menaka's Choice (2016) can be analysed as a feminist appropriation of Foucault's concept of Docility and Discipline as it evidently shows how the women characters of the novel suffocate under this surveillance and regulations. Menaka, a nymph of great beauty, who causes the ruination of great sage Viswamitra, initially symbolises a physical object of male carnal desire and simultaneously as an instrument of power. It is in this sense that women's experience of their own body is oppressive and painful as they are not congruent with women's perception of their identity and individuality. The history of seduction, personified by apsaras in Hindu mythology, is not only important to understand the relationship between men and women but also "the manner in which societies depict the victories and attraction between the sexes" (Aymard and Mukhiya 469).

Myth has been defined as "a mode of symbolic expression objectifying early human feeling and experience, (...) the product of the reflective or historical consciousness, or the search for scientific or philosophical truth" (Rahv 4). Myth does not have its discipline; hence, every discipline applies its theory on myth. From a feminist perspective, myth is an inhospitable terrain (Ostriker 71) through which patriarchy preserves its hegemonic ideology. As per the opinion of Shashi Deshpande (2003), Indian cultures have a strong vitality with mythologies as they serve the truth about human existence and their identity. However, these mythologies are the most powerful tool to establish patriarchy and attribute to women a sexual identity based on binary logic. In the Hindu epics they are the speakers of Dharma as McGrath states: "women in the epics are vigorous, authoritative, are often set the trajectory in which the narrative runs" (McGrath 15).

Prabhati Mukherjee underlines the importance of investigation of women psyche within the social structure of Hindu society as she writes: “...an investigation of the position of women will help us to appreciate the working of 
the male emphasized society"("Some Notes" 3). Revising mythological women from feminist point of view is a part of Conscienticization. Keohane, Rosaldo and Gelpi have discussed three stages at which women's collective consciousness can be understood: (a) Feminine Consciousness (b) Female Consciousness (c) Feminist Consciousness. All three stages cannot co-exist at any given moment, so the feminist critics do not focus on 'the women' - Sita, Draupadi, etc. but explore the experiences of those women. Today, the retellings of these biased narratives have a potential to alternate the conflict with power establishments and initiate a new mythology from women's point of view.

\section{The Origin of 'apsaras' in Hindu mythology}

The concept of apsara has been changing from the Vedic period to later Vedic period. D.D. Kosambi argues that apsaras occupied a distinguished place in the Vedic period; Apsaras like Menaka, Ghritachi, and Alambusa were perceived as mother goddess. However, in the later Vedic period they were degraded as celestial prostitutes. According to Bhagwat Purana, apsaras emerged from the churning of the ocean. In the Puranas, they have been portrayed as agents of seduction and temptation who are instructed by Indra to disturb the great Sages' penance, while other versions claim their emergence with seven Rishis to serve as wives of gods and daughters of pleasures (William 57).

The perception of apsara has been treated in Hindu mythology as a celestial being and as seducing beauties who by the display of their beauty and physical charm robbed the intellectual ascetic, to fulfil the 'divine purposes'. The Hari Vansa enumerates seven apsaras while Vayu Purana mentions fourteen apsaras. They are divided into various categories based on their role, as being daivika, 'divine', and laukika, 'worldly'. However, these various myths underline the common purpose of apsara that each apsara is "skillfully versed in the 64 ways to please the senses" (Pattnaik 22). Besides entertaining in Indra's court, Indra sends these apsaras to seduce great sages, thus stopping those sages from attaining their higher spiritual goal and those who fail to seduce often earn the wrath of great sages or kings.

One such tale is that of apsara Menaka and Viswamitra, which is one of the best-known stories of Hindu mythology. Menaka seduces sage Viswamitra and nullifies his penance. In Menaka's Choice, Kané gives central position to Menaka, whose significance lies in her being a celestial being and lover of Viswamitra. Interestingly, Kane portrays Menaka's character sharply in contrast to the 
representation of women in Hindu epics. She is discouraged to embrace a domestic life; this shows her non-docile and independent existence. Yet this discouragement opens up ground for questioning her individuality as Kané states, "Menaka asks her questions and she wants her answers. She questions her role not just of an apsara but that of a lover, a wife, a mother, and above all, a woman" (Paradox of Choice 216).

Apsaras are considered divine hence are powerful and unconfined beings. They have authority yet have no access to power and become the agents of the power structure. They are expected to be free from expectations and responsibilities, yet each is penalized for her transgression. The disciplinary system compels the individual to accept the surveillance as a norm and the absolute truth.

\section{Heaven: A disciplinary institution}

The novel begins with the birth of Menaka (the celestial being) from the ocean churning. Being a celestial body Menaka is a part of "Heaven", "Indralok" that is the disciplinary institution in Foucauldian perspective and a disciplined space where the rules and instructions are established to secure the power system. Heaven is a place that divides the individuals from others and each individual has its function; Foucault calls this division the art of Distribution (Hoffman 30) that produces the individual 'useful' for the system.

Kané repeatedly emphasizes this paradigm as Menaka is considered more as a body than an individual being that is often coerced and degraded as exemplified by the identification of Menaka with her body. The Apsara paradigm invokes most forcibly by her visual characterization, "she was slim but delicately voluptuous, her long, slender neck over slight shoulders, her creamy, shadowed cleavage heaving slightly..." (Kané 3) The control on activities of the body correlates the gesture of the body that further "constitute a genetic form of individuality by subjecting the body to the demand for perpetual progress toward an optimal end" (Hoffman 30). Here, Menaka represents an agent of allurement.

Menaka "is sexually objectified when her sexual parts or sexual functions are separated from the rest of her personality and reduced to mere instruments or else regarded as if they are capable of representing her" (qtd. in Teng 77) . Kané questions "was she just a water nymph?" as she is an instrument, she is born "to distract, destroy and ravish" (Kané 4). She is merely a seducing beauty 
who is born to destroy the mighty sage Viswamitra by her physical charm, as an instrument in the hand of powerful Indra. The identification of the person with her visual characterisation and sexuality becomes oppressive, especially, when this identification extends into an area of her rationality. Thus, they are the "anatomo-politics of the human body" 100 and the prime focus is on her docility, distribution, and her submission. In Foucauldian terms, this is the organisation of geneses. Foucault has discussed several techniques that are capable of generating the Docile person. Hence, the body plays an important role in the power system "to the body that is manipulated, shaped, trained, responds, becomes skilful and increases its force" (136). Having been appropriated as an instrument, Menaka can no longer be an individual body.

\section{The Organisation of 'Organic' Individuality and the Role of Apsara}

Heaven operates the disciplinary system by exerting control over each individual's body and thus produces organic bodies; "this individuality is 'organic' in so far as it lends itself to disciplinary practices all on its own, as if spontaneously and naturally" (Hoffman 29). Apsaras are trained to become docile bodies, which is a crucial part of the disciplinary system as bodies are expected to remain passive. They internalize them by treating themselves as an object and evaluate not only their outer appearance but also their inner thoughts. In the novel, Menaka is tied to her own identity as apsara, she inspires the works of artists, sculptures, and poets. "Yet lethal to whoever desired" (11) Kané questions her role, "was then Menaka, a sweet poison, like the halahal she had jestingly referred to?" (11) In this sense, she is the entity with the agency but the agency itself is controlled by other power. She acts in a way that identifies her as a non-docile body, as someone who is not obliged by the disciplinary system. However, it is Indra who wants her to take the role of 'seductress', 'the temptress of pleasure'. It should be performed intelligently, "the task might have proved well beyond their powers, had not Indra, the god of gods, stood behind them as a stealthy instigator" (83).

An Individual deliberately turns himself/herself into a subject, which may be called self-subjectification. Apsaras are placed in a multiplex power relation where they are taught to practice dance and to make themselves heavenly

100 The idea of 'anatomy of body politics' has been propounded by Michel Foucault. The idea centred on the body as a machine. It is a technique to control a large population through a disciplinary system. Foucault asserts, "The parallel increases of its usefulness and its docility" (139). 
beautiful to tantalize 'men' especially, who are intimidating to the power system. They view themselves more as celestial beings than as individuals with their desires and choices. They should be heartless, should provide transitory pleasure but unstable, they should not love they should be loved, "they were taught to be selfish and pitiless" (Kané 30).

They are expected to be a machinery of youth and beauty. As Kama, the god of love apprises: "Be the sexual-master of the sexual escalation! No words, it is a physical game-raw and fluid! Be sinuous, sensual, sensuous, and shameless!"(27). Again he hollers their duty as apsara: "you are artists, you are courtesans skilled to make certain, special men happy, to bewitch the strongest, and to weaken the toughest-they can be mortal man, asura, deva, rishi!" (27) This is the training part of their daily practices. Likewise, Menaka is trained with the notion of courtesans and women's sexuality and keeps herself busy with practicing dance. The disciplinary system does not only dominate apsaras' physical body but also their thoughts and ideas, "they were taught to be selfish and pitiless: they cared for their selves" (30). Similarly, Menaka is supposed to be free and confined yet not allowed to marry and have children. This shows the irony of their non-docility as Urvashi articulates, "Neither family nor marriage subjugates us. We have no husband, no sons, no daughters, indeed, no relations" (30).

Menaka is trained and operated according to the power system. However, any act of infringement of this power system may lead to her elimination from the heaven. When Menaka falls in love with Vasu and gets married to him by violating the rules of heaven, her act makes Indra furious, as they are not allowed to marry or have any relationship with others. Indra asks vehemently, "how dare you break the rules?" (48). Heavenly bodies are beautiful, immortal, and young but not for themselves but to fulfil the purpose of power. Later in the novel, the revelation of Menaka's pregnancy bewilders Indra, as being a 'dancing Nymph' she is not allowed to conceive. She has been created to please and appease, she cannot have a personal life as Indra proclaims, "You belong to us. You know that yet you decided to fall in love..." (44).

At this point, Menaka questions her identity not as an individual but as a subject of the power system and reveals the inner truth as she says, "you gave me all the weapons of love, sex, and desire but disarmed me of my capability of conscious choice and decision. Why? I can be a woman, but never a wife or a mother. Just a sexual slave. A whore" (47). Here, she uncovers the repressed 
truth of her docility. It creates a sharp distinction between Menaka as an individual and Menaka as a tool, a subject Indra expects her to be, and as a person, she wants herself to be. Here it is interesting to note that in patriarchal culture "the sexual anatomy of apsaras was challenging the notion of male authority, so that its subversive potentiality was sought to be appropriated by transforming their sexual autonomy into their sexual availability" (Shah 147). Eventually, she is just an assorted piece to be used and tossed by the power system of Indra. She laments that the likes of her are those who "....Have no choice, no voice, yet we (apsara) are to sing paens for him (Indra)" (61). They are compelled to act and look in certain ways unlike the 'wives' of devas who are allowed to marry and beget.

Consequently, Indra punishes her by giving two choices, either to give up her child or give up Vasu and heaven. As Kané reveals, "his offer was a sham but she knew she had a choice to refuse" (108). She gives up her child, Pramadvara, because she is bound to her duties as an Apsara. She chooses to abandon her child as the 'Instructive conversation' of Indra becomes the substratum of the disciplinary system in heaven. Here, Menaka presents all the alternatives she has as an apsara. Consequently, she observes her condition and discovers the requirements of an apsara.

Furthermore, power is a form of knowledge as it is "embodied and enacted rather than possessed, discursive rather than being deployed by them" (Gavent 1) Power is not imposed on anyone by force. It is neither agency nor structure. In this respect, Indra rectifies Menaka's act of seduction not as dangerous but as salvation, as he states, "Seducing dangerous men to save the world, is not whoring it is salvation!" (Kane 47). Indra, in his defence sees this act as something moral instead of coercion, and signifies it as an accepted form of truth. Indra makes the act of seduction as not only necessary and positive, but also efficacious for society.

Moreover, Menaka and Vasu's relationship is intimidating to Indra's power system and consequently, Vasu is convicted for committing adultery and challenging Indra. Indra makes him a drunkard and a low man in the eyes of everyone, and to execute his plan he gets support from Rambha. Within Foucault's concept of surveillance, Rambha is an individual body who holds the rank of chief of apsaras, in this way she is the 'other hierarchy' who makes this system perpetual as 'this network holds.' Indra threatens Vasu and throws his Vajra at Vasu resulting not in Death but rather in the elimination of Vasu from 
Heaven in the form of a Monster. Menaka, however, is aware, that the elimination of Vasu has nothing to do with adultery but it is due to Indra's jealousy. Indra following the forms of punishment punishes Vasu for the purpose of establishing a hierarchy of good and bad subjects.

At this point, Menaka withdraws herself from everything and becomes indifferent. She decides to be reticent about her daily routine. Her indifference and aloofness are, thus, her resistance against Indra's dominating ideology. Although in her detached nature she opts to become nobody than an Apsara with no purpose or pleasure she becomes cold and heartless. According to Sally Bayley, "monitoring Panopticon is a statement of both self-defence and selfassertion against the intrusive gaze of the outsiders" (Bayley 162). However, from the Foucauldian perspective resistance to power is impossible, by resisting one becomes the active member of the power system, and takes the counterhegemonic position within the social-formation.

In this sense, Menaka's aloofness insinuates her freedom. In another way, Menaka's aloofness is not her withdrawal from activity as she is still not a passive character rather is an active character who uses her aloofness to make Indra realise his deed and to deliver justice on her expelled beloved, Vasu, as she rages and warns, "I announce right now, right here, that I refuse to dance in this court till Vasu returns" (Kane 82). Her humiliation against Indra is "the element of liberty" as the sufferer takes pleasure in the suffering of the dominant. The moment Menaka lays her conditions before Indra she becomes more powerful. Here, the notion of her power is twofold; she is powerful yet submits to power she cannot escape from heaven and still relies on Indra, on the other hand, Indra cannot use his power to make her what he wants. With respect to the resistance of an apsara Jamison says, "She is capable of 'independent' action and demonstrates a 'resourceful contrivance' in the face of resistance. However, our reading of the epic allows us to problematize such a simplistic assessment of apsara" (qtd. in Shah 15).

Menaka does not remain ignorant of her position for long. Furthermore, her realisation leads her to escape from heaven, as she attempts to subvert the disciplinary system by helping Indra plotting against Viswamitra. In this way, becoming a part of Indra's plot she sees vishvamitra, her only "legitimate opportunity of escape" (Kané 108). Her docility makes her realise that she cannot rely solely on her status as 'apsara' she must lure someone outside of heaven. Furthermore, she fails in her resistance against power dynamics in Foucauldian 
sense because it is more than negating as this form of power involves aptitude of individual bodies without allowing these skills as a medium of resistance, "Disciplinary power controls the body to effectuate this result through the production not only of an individual but also of individuality, the amalgam of qualities that render an individual distinct from others" (Arendt 454).

Kané further questions her escape from heaven, "how could she escape and where could she hide?" (108). However, to accomplish her freedom she obeys Indra. It is an ironic strategy as she becomes more powerless and objectified. Her body becomes a signifier as to lure Sage Vishvamitra. Indra appeals to Menaka, "I need you to go down on Earth, seduce him, sap him entirely of all his powers and find a way to trap him into domestic bliss on more permanent terms" (102). This strategy is more in tune with a patriarchal ideology where a woman's sexuality has been objectified and utilised for the establishment of power. Shah observes, "not only they denied any autonomy as to their (apsara) desires, they are consciously used as an inert tool for scoring victories in the battle amongst males - specifically, Indra and the tapasvy" (152).

Menaka, being an institutionalized agent, performs what power system expects of her and presents her as merely a docile body who is 'guided' by Indra. She functions on Indra's command to woo, to entrap, and to win men with her sensual moves and agrees to entrap the intellectual sage, Vishvamitra, by using her feminine charm. As Kané interrogates, "was Menaka up to her tricks again?" (108) yet, it is her adjustment for her purpose. She adopts her old self only to execute her plan to escape from the Indralok. Fear of elimination and alienation motivates Menaka to engage in the environment of sexual baits. In this way, once again, she finds herself at the point she started from. As such, this suggests that she has detached herself from any power and becomes the principal of her subjection. Menaka assumes responsibility for the constraints of power.

\section{Internalised authority: Indra's panopticon gaze}

Foucault's concept of Panopticism indicates 'internal surveillance'. Menaka displays it as a sexual object; she has been depicted as pleasure of gaze that is determined and planned by active male and passive female, hence, Menaka acts according to the man's phantasy. Menaka successfully seduces Viswamitra even without using 'Kama's Arrows' and presents herself as an image of man's desirable gaze as Kama says, "no saints or scoundrel could resist such a temptation" (117). Now, the question is, whether this desirable gaze empowers 
Menaka. Indra commands Kama to shoot the love arrow without Menaka's consent, as he wants her to forget Vasu. Kama gives a warning to Indra as he asserts, "she needs to be in control, to manipulate him. If in love herself, she won't be able to hold sway over him and accomplish her given task" (119). Nevertheless, Indra despite the dire consequences orders Kama to shoot.

Here, Menaka's self-control and independence compromised on behalf of man's needs; Menaka plays her role as Indra's marionette. She is left disempowered and passive according to Boetticher: "She is the one, or rather the love she inspires in the hero or else the concern he feels for her, who makes him act the way he does in herself the woman has not the slightest importance" (qtd. in Mulvey 7). Here, she has been reduced to a powerless character and a tool in the hands of powerful Indra. Foucault also distinguishes the insidious effect of gaze that is internalized as he says, "the major effect of the Panopticon... [is] to induce in the inmate a state of conscious and permanent visibility that assures the automatic functioning of power" (Foucault 201).

Later in the novel, when Menaka falls in love with Sage Viswamitra and the moment she realizes the consequences of this relationship, the uncertainty of her future arises as she discerns herself as an instrument in the power system. She oscillates between the dream of domestic life with Viswamitra and her role as an Apsara, as Kama reminds her, "He (Viswamitra) was never yours to take. He was a target; you are a strategy" (Kané 143). Her inner turmoil threatens her own 'identity' as an Apsara, "Menaka was supposed to be providence to change the future of Viswamitra, the means and the reason for his fall from the glory. She had fallen a victim herself" (114). Not having any alternatives, she internalises the norms of the existing power system. Indra questions her presence with Viswamitra: "How many more years do you intend to be with him, it cannot be forever! (156)". Knowing the consequences, she replies, "I do, oh, I do. I cannot allow myself to forget that I am a creature of heaven. I do not belong here..." (156). However, the internalisation is a long process of perplexity and discomposure of self-transformation but with a subtle control on individual as Kane asserts, "She was more docile, more resigned" (156).

She declares herself defeated in front of mighty Indra, as she confesses to Indra. Indra creates an uncanny fear and being a celestial body, she feels the threat of powerful Indra that keeps her withdrawn. Indra looks at her like "google-eyed headlines" (215) staring at her constantly, which is similar to disciplinary gaze. This does not function as the actual act of watching but this is 
an internalized belief of the individual, of the constant observation. On the other way, the act of gaze is practiced occasionally, not frequently or all the time. Constant coercion is a technique of docility where the individual is constantly aware of being watched all the time.

\section{Conclusion}

The disciplinary system, as a method of subversion, uses internalization, surveillance gaze and self-discipline. Menaka's performance has shown a way that embodies injustice and divinity since she is an apsara. The novel not only depicts a new form of self-discipline that eradicates any resistance, but also "the manner in which societies depict the victories and attraction between the sexes" (Shah 149). Menaka cannot escape from the network of power and resistance, it is just a ubiquitous and metaphorical concept.

Kané has situated her heroine in the field of combat where her consciousness continuously struggles between her docility and her individuality. The docility of Menaka's body is the ultimate result of "creating desire, attaching individuals and their behaviour and bodies are judged and against which they police themselves" (Sawicki 68) manifests a resourceful contrivance. Thus, Menaka is both a site of docility and resistance, as she can transcend Indra's rules, but also finds herself shackled by her position as an apsara who ultimately fails to challenge the hegemonic system. Kane has managed to construct the mythology that comments on its sources, encompasses women's oppression and subjection, and unveils their untold desires and experiences. The study also reveals that women's body has been shown as a threat to men's spirituality. It shows patriarchal control over women's choices, which is quite contrary to the title of the novel.

\section{Works Cited}

Arendt, H. The origins of totalitarianism. Duke University Press, 2007.

Aurobindo, S. The harmony of virtue (Vol. 3). Pondicherry: Sri Aurobindo Ashram, 1992.

Aymard, M \& Mukhiya, H. (Eds.). French Studies in History (Vol. 2), The Departure. Orient Longman, 1990. 
Bayley, Sally. "I have your head on my wall: Sylvia Plath and the Rhetoric of Cold War America." European Journal of American Culture, Vol. 25, no.3, 2007: 155-71.

Deshpande, S. Telling Our Own Stories. Writing From the Margin and Other Essays. India: Viking, Penguin Books. 2003: 86-100.

Foucault, Michel. Discipline and punish: The birth of the prison (A. Sheridan, Trans.). 1977. Originally Published as Surveiller et punir: Naissance de la prison. Paris: Gallimard, 1995.

Gaventa, Jonathan. "Power after Lukes: an overview of theories of power since Lukes and their application to development." Brighton: Participation Group, Institute of Development Studies 2003: 3-18.

Hoffman, M. "Disciplinary Power" in Dianna Taylor (Ed.) Michel Foucault: Key Concepts. Durham: Acumen. 2011: 20-35.

Kané, K. (2016). Menaka's Choice. Rupa, 2016.

Kané, K. (23 march, 2016). Paradox of Choice. (Interview) Deccan Chronicle.

www.deccanchronicle.com/lifestyle/books-and-art/230316/paradox-ofchoice.html

Keohane, Nannerl O., Michelle Z. Rosaldo, and Barbara C. Gelpi. "Feminist theory: A critique of ideology." Ethics, vol. 94, no. 41984.

Kosambi, D.D. Myth and Reality, Bombay: Popular Prakashan. 1962.

Lad, G. P. Mahabharata: "A mythology in the Making" in Bulletin of the Deccan College Research Institute, vol. 2 1985: 47-57.

McGrath, K. Stri: Feminine Power in the Mahabharata. Orient Blackswan Pvt. Ltd, 2011.

Mukherjee, P. Hindu Women: Normative Models, Hyderabad: Orient Longman, 1998.

Mulvey, L. Visual pleasure and narrative cinema. Screen, vol.16, no.3, 1985: 6-18

Ostriker, Alicia. "The thieves of language: Women poets and revisionist mythmaking." Signs: Journal of Women in Culture and Society, vol.8, no.1, 1992: 68-90.

Pattanaik, D. Myth = Mithya: A Handbook of Hindu Mythology. New Delhi: Penguin, 2006.

Rahv, P. The myth and the powerhouse. New York: Farrar, Straus and Giroux. 1965.

Sawicki, J. Disciplining Foucault: Feminism, power, and the body. New York: Routledge, Chapman and Hall. 1991.

Shah, S. The making of womanhood: gender relations in the Mahābhārata. New Delhi: 
Manohar, 1995.

Smith, James KA. Desiring the kingdom (cultural liturgies): Worship, Worldview, and Cultural Formation. Michigan: Baker Academic, 2009.

Teng, Fei, et al. "Sexual objectification pushes women away: The role of decreased likability" in European Journal of Social Psychology, vol. 45, no. 1, 2015: 77-87.

Wadley, Susan S. "Women and the Hindu tradition." Signs: Journal of Women in Culture and Society, vol. 3 no. 1, 2007: 113-25.

Williams, G.M. Handbook of Hindu Mythology. New York: Oxford University Press, 2008. 